\title{
A chromosomal investigation of some European Leiodidae (Coleoptera), with particular focus on Spanish subterranean Leptodirini
}

\author{
Robert B. Angus ${ }^{1,2}$, David B. Edwards ${ }^{2}$, Carlos G. Luque ${ }^{3}$, Lucia Labrada ${ }^{3}$ \\ I Department of Entomology, The Natural History Museum, Cromwell Road, London SW7 5BD, UK2 School \\ of Biological Sciences, Royal Holloway, University of London, Egham, Surrey TW20 OEX, UK 3 Gestión del \\ Patrimonio Bioespeleológico. IMPRESS Group ${ }^{T M}$ Consulting S.L.; Grupo de Espeleología e Investigaciones \\ Subterráneas "Carballo-Raba»; P.O. Box 879; 39080 Santander; Spain \\ Corresponding author: R.B. Angus (r.angus@rhul.ac.uk) \\ Academic editor: C. Nokkala | Received 21 December 2011 | Accepted 29 February 2012 | Published 26 March 2012 \\ Citation: Angus RB, Edwards DB, Luque CG, Labrada L (2012) A chromosomal investigation of some European \\ Leiodidae (Coleoptera), with particular focus on Spanish subterranean Leptodirini. Comparative Cytogenetics 6(2): \\ 127-139. doi: 10.3897/CompCytogen.v6i2.2575
}

\begin{abstract}
Karyotypes are shown for Leiodes calcarata (Erichson, 1845), Catops coracinus Kellner, 1846, Cantabrogeus luquei (Salgado 1993), Espanoliella luquei Salgado \& Fresneda, 2005, Fresnedaella lucius Salgado, Labrada \& Luque 2011, Notidocharis uhagoni (Sharp, 1872), Quaestus (Quaesticulus) pasensis Salgado, Labrada \& Luque, 2010, all of which are shown to have a diploid number of 20 autosomes plus Xy (ふ) or XX (ㅇ) sex chromosomes, as well as an as yet undescribed triploid species of the genus Cantabrogeus Salgado, 2000. These results are contrasted with published information, all on Leptodirini, which lists 10 species as having diploid numbers of $22+\mathrm{Xy}$ or XX. It is shown that the higher chromosome number $(\mathrm{n}=11+$ $\mathrm{X}$ or $\mathrm{y}$ ) previously reported refers exclusively to the more derived Leptodirini ("infraflagellates") whereas the lower number $(\mathrm{n}=10+\mathrm{X}$ or $\mathrm{y})$ refers to the less derived surface-dwelling forms and the less derived Leptodirini ("supraflagellates").
\end{abstract}

\section{Keywords}

Chromosomes, Leiodidae, Leptodirini, Leiodes Latreille, 1796, Catops Paykull, 1798, Cantabrogeus Salgado, 2000, Espanoliella Georgiev, 1976, Fresnedaella Salgado, Labrada \& Luque, 2011, Notidocharis Jeannel, 1956, Quaestus Schaufuss, 1861, Cantabria, triploid

Copyright Robert B. Angus et al. This is an open access article distributed under the terms of the Creative Commons Attribution License 3.0 (CC-BY), which permits unrestricted use, distribution, and reproduction in any medium, provided the original author and source are credited. 


\section{Introduction}

Published information on the chromosomes of Leiodidae is very limited and refers exclusively to subterranean species of the tribe Leptodirini (Durand and JuberthieJupeau 1980; Alegre and Escolá 1983; Buzila and Marec 2000). In all data on 10 species have been reported, all with the diploid number $24\left(22+\mathrm{Xy}\left({ }^{\Uparrow}\right), 22+\mathrm{XX}(\right.$ (q) $)$. Buzila and Marec (2000) considered this to be the basic chromosome number for the family Leiodidae.

However, investigation of two surface-dwelling forms in 2006 by D.B. Edwards as part of a student project supervised by R.B. Angus, revealed the diploid number $20+\mathrm{Xy}$ in the males studied. This was a surprise and remained a puzzle until, in December 2009 R.B. Angus received a request from I. Ribera (Barcelona) for help in determining the chromosome number of a cave-dwelling leptodirine from the Cantabria region of northern Spain. Despite intensive searching by C.G. Luque and L. Labrada, only females of this species had been found in the cave so that they suspected the species might be parthenogenetic and wondered if it might be triploid. Investigation of this material showed that the species was indeed triploid, with consistent finding of 33 chromosomes per nucleus. However, while the confirmation that this was a triploid parthenogenetic species was very satisfying, it also added to the puzzle over the diploid number for Leiodidae as this species is was a subterranean member of the tribe Leptodirini, from which the diploid number 24 had been consistently reported. It was therefore decided to extend the investigation to some of the bisexual species to see what the diploid number was in species from Cantabria.

The tribe Leptodirini Lacordaire, 1854 (= Bathysciini Reitter 1906) of the family Leiodidae (Newton 1998, Perreau 2000) is the second largest group (after Carabidae) of subterranean Coleoptera. Nearly all Leptodirini, with a few notable exceptions, inhabit caves or deep soil layers in the Mediterranean basin. This area includes the north and east of the Iberian Peninsula, some Mediterranean islands such as Corsica, Sardinia and Sicily, the southern Alps, Italian and Balkan peninsulas, Carpathian Mountains, southern Russia, the Caucasus, Middle East and Iran (Perreau 2000, 2004; Salgado et al. 2008). The monophyletic origin of the tribe's western Palaearctic core (Leptodirini excl. Platycholeina) is well supported by both morphological (Fresneda et al. 2007) and molecular (Ribera et al. 2010) evidence.

\section{Material and methods}

The material investigated is listed in Table 1, and the localities from which the material was obtained are marked on the maps shown in Fig. 1. In all cases the number of specimens from which successful preparations have been obtained is given. As these beetles are frequently very small ( $2 \mathrm{~mm}$ or less) the success rate was generally low and preparations were attempted on considerably more specimens than are listed as suc- 
Table I. Material used, localities, map numbers, numbers of specimens giving successful preparations.

\begin{tabular}{|c|c|c|}
\hline Species & Locality with No. on map & $\begin{array}{c}\text { Number giving } \\
\text { successful } \\
\text { preparations }\end{array}$ \\
\hline Leiodes calcarata (Erichson, 1845) & ENGLAND. SurreY: Virginia Water (No. 1) & $1 \delta^{\top}$ \\
\hline Catops coracinus Kellner, 1846 & ENGLAND. SurREY: Virginia Water (No. 2) & $10^{\pi}$ \\
\hline Cantabrogeus sp. (triploid) & $\begin{array}{l}\text { SPAIN. Cantabria: Municipal District of San } \\
\text { Roque de Riomiera, Covallarco cave (No. } 3 \text { ) }\end{array}$ & 7우우 \\
\hline C. luquei (Salgado, 1993) & $\begin{array}{l}\text { SPAIN. Cantabria: Municipal District of } \\
\text { Penagos, Los Gentiles cave (No. } 4 \text { ) }\end{array}$ & $2 \hat{\jmath} \widehat{\partial}, 1$ ㅇ \\
\hline $\begin{array}{l}\text { Espanoliella luquei Salgado \& } \\
\text { Fresneda, } 2005\end{array}$ & $\begin{array}{l}\text { SPAIN. Cantabria: Municipal District of } \\
\text { Santoña, Merino cave (No. 5) }\end{array}$ & 10,1 우 \\
\hline $\begin{array}{l}\text { Fresnedaella lucius Salgado, Labrada } \\
\text { \& Luque, } 2011\end{array}$ & $\begin{array}{l}\text { SPAIN. Cantabria: Municipal District of } \\
\text { Selaya, La Canal de la Cubía cave (No. 6) }\end{array}$ & $1 \hat{O}^{\hat{2}}, 1$ 우 \\
\hline Notidocharis uhagoni (Sharp, 1872) & $\begin{array}{l}\text { SPAIN. CANTABRIA: Municipal District of } \\
\text { Ramales, Cullalvera cave-entrance (No. 7) }\end{array}$ & $2 \hat{\partial}$ \\
\hline $\begin{array}{l}\text { Quaestus (Quaesticulus) pasensis } \\
\text { Salgado, Labrada \& Luque, } 2010\end{array}$ & $\begin{array}{l}\text { SPAIN. Cantabria: Municipal District of } \\
\text { Luena, El Rellano del Mazo cave (No. 8) }\end{array}$ & $2 \hat{\partial} \hat{\sigma}$ \\
\hline
\end{tabular}

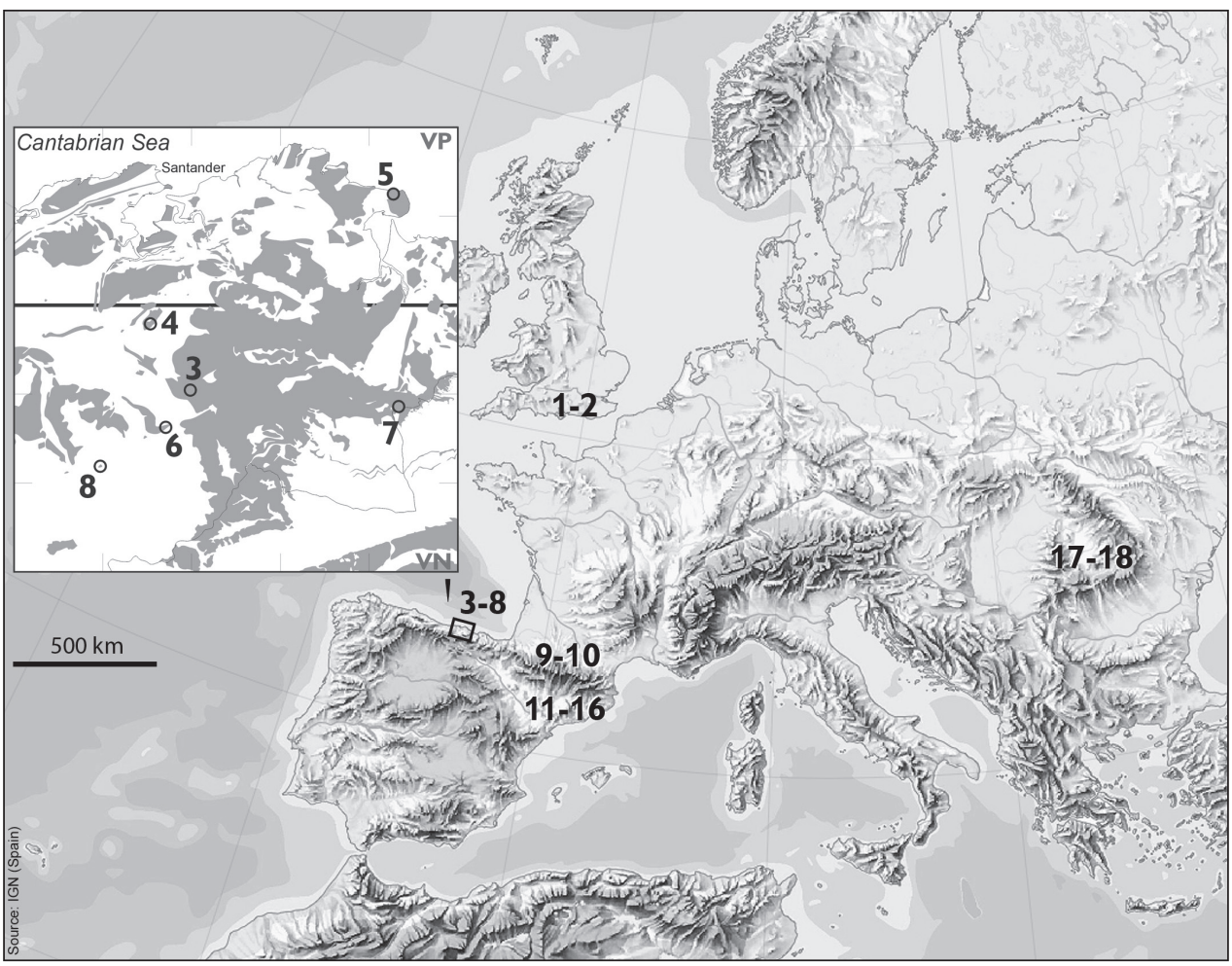

Figure I. Maps showing the collection sites of the material used in this paper (Nos 1-8), previously published material (Nos 9-18, see Table 2) and areas with carbonate rock outcrops in Cantabria, N Spain (squares $10 \times 10 \mathrm{~km}$ ). See Table 1 for explanation of numbers $1-8$, and note that neighbouring sites may share the same number. 
cessful. It should also be noted that there was often considerable mortality in transit, even when material was sent express in cooled containers.

The methods of chromosome preparation are as described by Dutton and Angus (2007). The remains of the beetles are either mounted on cards or kept in tubes of $70 \%$ ethanol, in the Natural History Museum in London.

For assessment of the chromosomal data in terms of DNA-derived phylogeny we used the dataset from Ribera et al. (2010), plus newly obtained sequences of various Leptodirini species. DNA was extracted from whole specimens with DNeasy Tissue Kits (Quiagen GmbH, Hilden, Germany) in a non-destructive manner to preserve voucher specimens for subsequent morphological study. DNA voucher specimens are deposited in the Institute of Evolutionary Biology (Barcelona, Spain). Seven gene fragments were sequenced: five mitochondrial ( 3 ' end of cytochrome c oxidase subunit 1 , cox 1; an internal fragment of cytochrome b, cyt $b$; and 5 'end of large ribosomal unit $16 \mathrm{~S}$ rDNA plus the Leucine transfer RNA gene plus the 3' end of NADH dehydrogenase subunit $1, \operatorname{rrnL}+\operatorname{trn} L+n a d 1$, and two nuclear (5' end of the small ribosomal unit $18 \mathrm{~S} \mathrm{rDNA}, S S U$, and an internal fragment of the large ribosomal unit $28 \mathrm{~S}$ rDNA, $L S U$ ). For each fragment both forward and reverse sequences were obtained. Sequences were assembled and edited using Sequencher TM 4.1.4 (Gene Codes, Inc., Ann Arbor, MI). Phylogenetic analysis was conducted using maximum likelihood as implemented in the on-line version of RAxML (which includes an estimation of bootstrap node support, Stamatakis et al. 2008), using GTR+G as the evolutionary model.

\section{Results}

\section{Surface forms}

Catops coracinus. $2 \mathrm{n}=20+\mathrm{Xy}(\widehat{)})$. Giemsa-stained mitotic chromosomes (unbanded), arranged as karyotypes are shown in Fig. 2 a (from mid-gut) and b (from testis). The autosomes are all submetacentric and show an even decrease in length so that pair 10 is about half the length of pair 1. The $\mathrm{X}$ chromosome is also submetacentric and is the longest chromosome in the nucleus, about twice the length of autosome 1 . The $y$ chromosome is small, almost dot-like. First metaphase of meiosis is shown in Fig. $5 \mathrm{f}$, which shows the 10 autosomal bivalents and the large $\mathrm{X}$ chromosome associated with the $y$ in the typical "parachute" association $\left(\mathrm{Xy}_{\mathrm{p}}\right)$ of Polyphaga (Smith 1950; Smith and Virkki 1978). Second metaphase of meiosis is shown in Fig. 5, g ( $\sigma^{\lambda}$-determining, with a y chromosome) and $\mathrm{h}$ ( 9 -determining, with an $\mathrm{X}$ chromosome). The small $\mathrm{y}$ and large $\mathrm{X}$ (both labeled) are very distinct in these preparations.

Leiodes calcarata. $2 \mathrm{n}=20+\mathrm{Xy}(\widehat{\widehat{O}})$. Unbanded Giemsa-stained mitotic chromosomes from testis are shown in Fig. 2 c. The autosomes and X chromosome are all metacentric or submetacentric. The $\mathrm{X}$ chromosome is about the same size as autosome 1 , which appears similar in size to that of Catops coracinus (compare Fig $1 \mathrm{~b}$ and c). The autosomes show an even decrease in length from pairs $1-8$, which pair 8 about half 


\section{$\begin{array}{lllllllllll}1 & 2 & 3 & 4 & 5 & 6 & 7 & 8 & 9 & 10 & \mathrm{Xy}\end{array}$ а

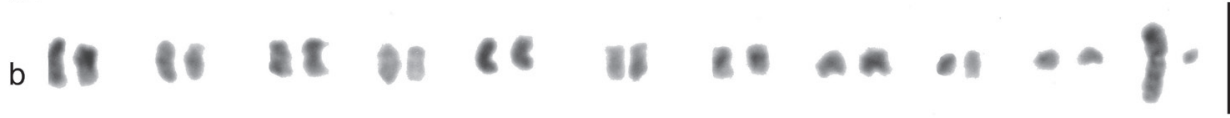

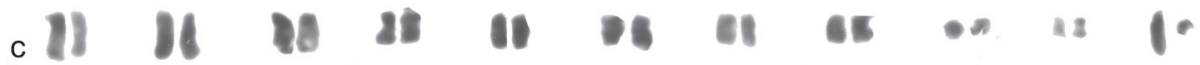

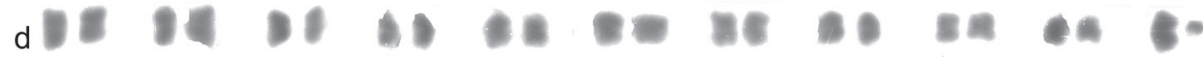

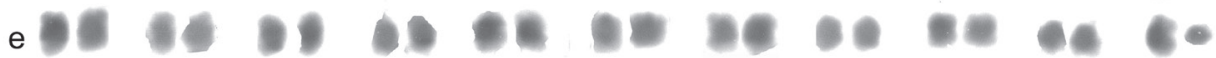

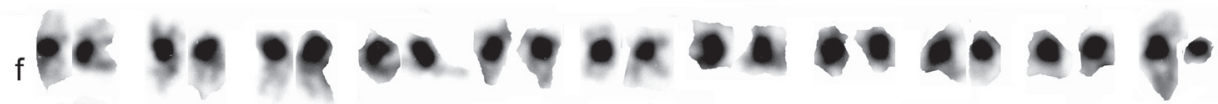

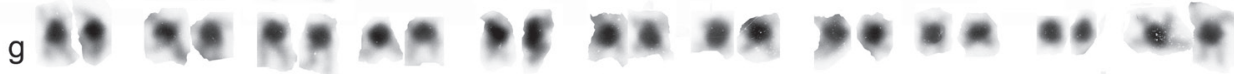

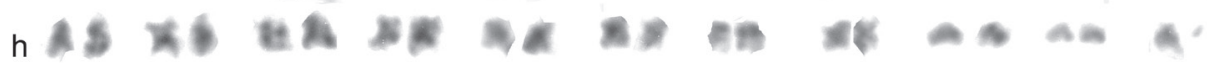

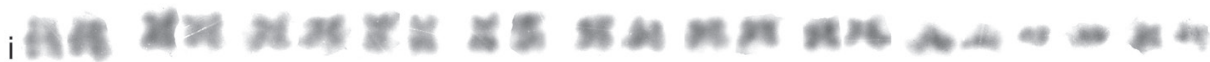

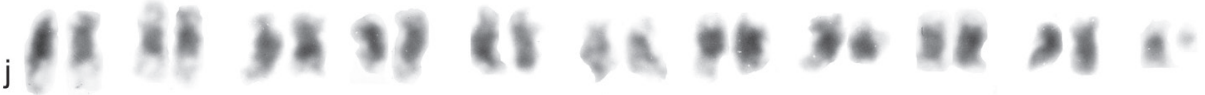

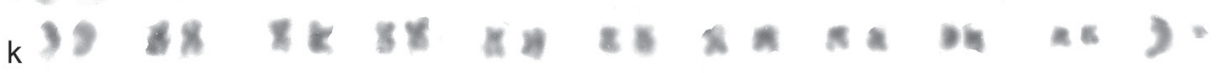 1 8 ,

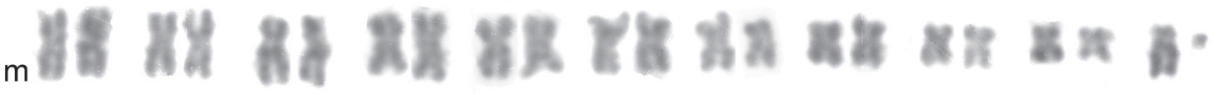

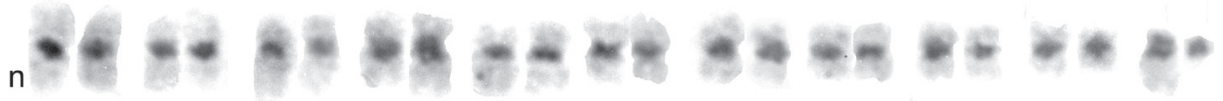

Figure 2. Mitotic chromosomes of Leiodidae, arranged as karyotypes: a, b Catops coracinus, unbanded a mid-gut $\mathbf{b}$ testis $\mathbf{c}$ Leiodes calcarata, testis $\mathbf{d}-\mathbf{g}$ Cantabrogeus luquei, mid-gut $\mathbf{d}$, e $\widehat{\partial}$ unbanded $\mathbf{f} \widehat{\partial}$ C-banded $\mathbf{g}+$ C-banded $\mathbf{h}, \mathbf{i}$ Espanoliella luquei, mid-gut, unbanded $\mathbf{h} \widehat{\delta} \mathbf{i}+\mathbf{j}$ Fresnedaella lucius, testis, C-banded $\mathbf{k}$, I Notidocharis uhagoni, Ô, mid-gut $\mathbf{k}$ unbanded I the same nucleus C-banded $\mathbf{m}, \mathbf{n}$ Quaestus pasensis, mid gut $\mathbf{m}$ unbanded $\mathbf{n}$ the same nucleus C-banded. Scale bar $=5 \mu \mathrm{m}$.

the length of pair 1 . There is then an abrupt decrease to pairs 9 and 10 , which are about half the length of pair 8. The y chromosome is dot-like. Zygotene of first division of meiosis is shown in Fig. 5 a, where the heavily condensed Xy bivalent is distinct. Fig. $5 \mathrm{~b}-\mathrm{d}$ shows first metaphase, with the $\mathrm{Xy}_{\mathrm{p}}$ bivalent very clear. Fig 5 e shows a second metaphase nucleus, with the y chromosome clearly present.

\section{Diploid cave-dwelling Leptodirini}

Cantabrogeus luquei. $2 \mathrm{n}=20+\mathrm{Xy}(\widehat{)}), 20+\mathrm{XX}($ (†). Unbanded Giemsa-stained mitotic chromosomes from mid-gut cells are shown as karyotypes in Fig 2, d, e $(\widehat{\jmath})$, and 
chromosomes from a C-banded $\hat{o}$ mid-gut nucleus is shown in Fig 2 f. Fig. $2 \mathrm{~g}$ shows chromosomes from a C-banded $O$ mid-gut nucleus. The chromosomes shown in Fig $2 \mathrm{e}$ and $\mathrm{f}$ are shown as found in Fig. $3 \mathrm{a}$, b. All the autosomes, and the $\mathrm{X}$ chromosome are metacentric with heavy centromeric C-bands. The autosomes show an even decrease in size along the karyotype, with pair 10 about half the length of pair 1 . The $\mathrm{X}$ chromosome, about $1.5 \times$ the length of autosome 1 , is the largest in the nucleus. The $\mathrm{y}$ chromosome is a relatively large dot. These preparations are completely consistent with one another and leave no doubt that $20+\mathrm{Xy}$ or XX is the true diploid number for this species.

Espanoliella luquei. $2 \mathrm{n}=20+\mathrm{Xy}(\widehat{)}), 20+\mathrm{XX}(+)$. Unbanded Giemsa-stained mitotic chromosomes from mid-gut cells are shown as karyotypes in Fig. $2 \mathrm{~h}(\widehat{)})$ and $\mathrm{i}($ ( $)$, and as found in Fig. 3 c, d. No C-banded preparation is available. The chromosomes in these preparations are all rather condensed, but appear either metacentric or submetacentric, with autosome pair 1 distinctly longer than the others, and a gradual decrease in length from pairs $2-10$. The $\mathrm{X}$ chromosome appears similar in length to the medium-sized autosomes and the y chromosome is dot-like. As with C. luquei, the preparations are consistent with one another and leave no doubt that the chromosome number reported here is correct.

Fresnedaella lucius. $2 \mathrm{n}=20+\mathrm{Xy}(\widehat{)}), 20+\mathrm{XX}($ (q). Fig. $2 \mathrm{j}$ shows spontaneously C-banded Giemsa-stained mitotic chromosomes from testis. Fig 3 e shows these chromosomes as found. The female preparations (not shown) were from mid-gut, completely unbanded and with the chromatids beginning to separate following maximum contraction at metaphase. They are, however, adequate to confirm the chromosome number. Spontaneous C-banding was frequent among testis preparations from these Leptodirini, but in most cases the preparations were not adequate for preparation of karyotypes. The $\mathrm{X}$ chromosome is the smallest in the nucleus, apart from the dot-like y. The C-bands are particularly weak in autosome 6 and slightly weaker than most in autosome 2 and the $\mathrm{X}$ chromosome, but in the remaining autosomes they are very strong. All the autosomes and the $\mathrm{X}$ chromosome are metacentric to submetacentric.

Notidocharis uhagoni. $2 \mathrm{n}=20+\mathrm{Xy}(\widehat{\circlearrowright})$. Fig. $2 \mathrm{k}, 1$ shows karyotypes from a $\widehat{\sigma}$ mid-gut cell, unbanded and C-banded. These chromosomes are shown as found in Fig. $3 \mathrm{f}, \mathrm{g}$. The autosomes and X chromosome are all metacentric or submetacentric, with small centromeric $\mathrm{C}$-bands. The $\mathrm{X}$ chromosome, about twice as long as autosome 1 , is the longest in the nucleus, and the autosome lengths decrease fairly evenly along the karyotype, with autosome par 10 about half the length of pair 1 . The y chromosome is dot-like. As with the other species, the preparations are consistent and there is no reason to doubt the number obtained.

Quaestus pasensis. $2 \mathrm{n}=20+\mathrm{Xy}\left({ }^{\Uparrow}\right)$. Fig. $2 \mathrm{~m}$, $\mathrm{n}$ shows karyotypes from a mid-gut cell, unbanded and C-banded, and Fig. $3 \mathrm{~h}$, i shows these chromosomes as found, before and after C-banding. Autosome pair 3 and the X chromosome are more or less subacrocentric while the other autosome pairs are metacentric to submetacentric. The autosome pairs decrease in length evenly along the karyotype, with pair 10 slightly less than half the length of pair 1 . The $\mathrm{X}$ chromosome is about as long as autosome pair 5 

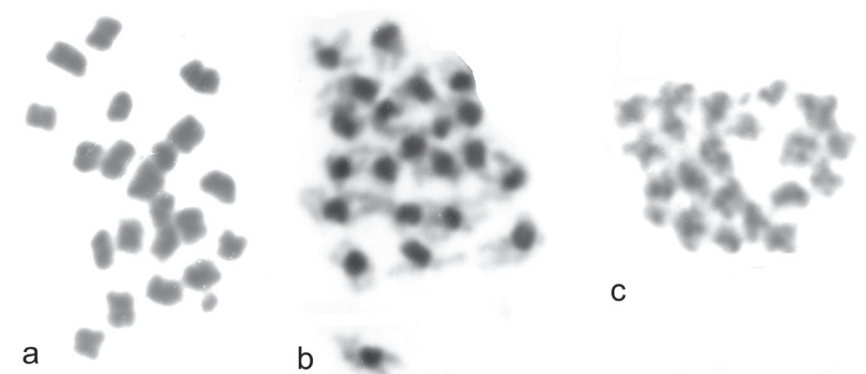

C

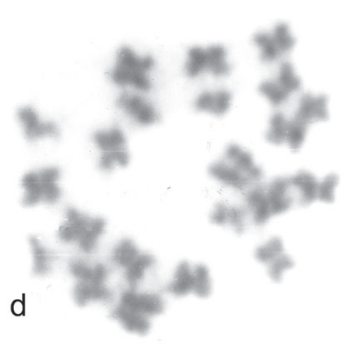

b

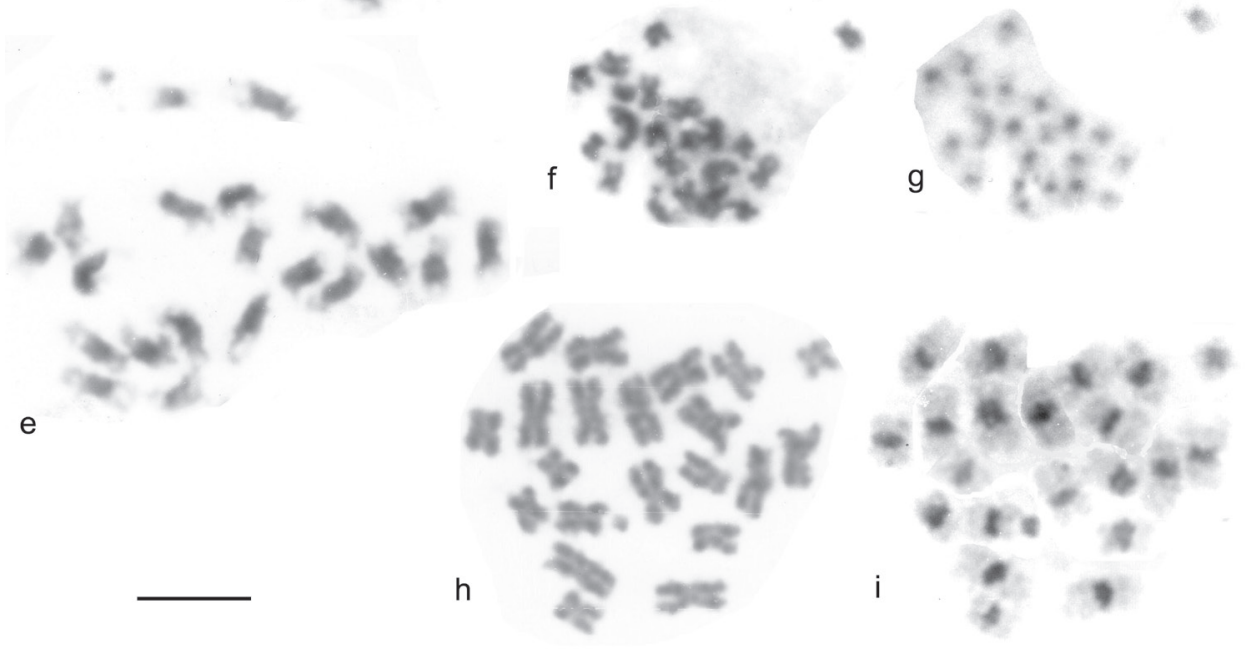

Figure 3. Giemsa stained mitotic chromosomes of Leptodorini as found. a, b Cantabrogeus luquei, midgut cell a plain b C-banded c, d Espanoliella luquei, mid-gut cells, plain c $\hat{O} \mathbf{d} q$ e Fresnedaella lucius, testis, C-banded $\mathbf{f}, \mathbf{g}$ Notidocharis uhagoni, $\widehat{O}$, mid-gut cell $\mathbf{f}$ plain $\mathbf{g}$ the same nucleus C-banded $\mathbf{h}, \mathbf{i}$ Quaestus pasensis, $\widehat{O}$, mid-gut cell $\mathbf{h}$ plain $\mathbf{i}$ the same nucleus C-banded. Scale bar $=5 \mu \mathrm{m}$.

and the y chromosome is dot-like. The centromeric C-bands are distinct, with those of autosome pairs 1 and 4 about twice the size of the others. As with the other species, the preparations obtained are completely consistent with one another and leave no reason to doubt their accuracy.

\section{Triploid species}

Cantabrogeus sp. (Salgado et al. in press) $3 \mathrm{n}=33$ (P). Fig. 4 shows mid-gut chromosomes of this species. Two nuclei are shown, both unbanded (Giemsa-stained) and Cbanded. Unbanded and C-banded karyotypes from the nucleus shown in Fig. $4 \mathrm{a}$ and $\mathrm{b}$ are shown as Fig. $4 \mathrm{e}$ and $\mathrm{f}$. As only females are present it is not possible to identify the $\mathrm{X}$ chromosome, but the results are totally consistent with a triploid number and a haploid complement of $10+\mathrm{X}$. Pairs 7 and 11 are subacrocentric, pairs 3, 5, 8 and 10 are clearly submetacentric, and the remainder are more or less metacentric. The 


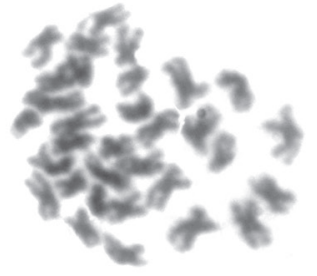

a

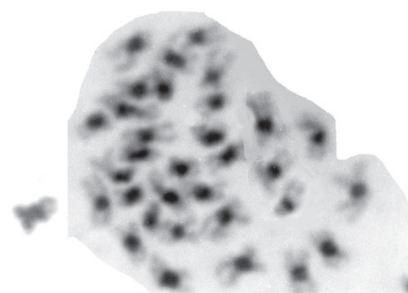

b

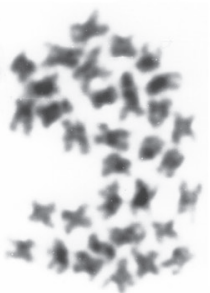

$\mathrm{C}$

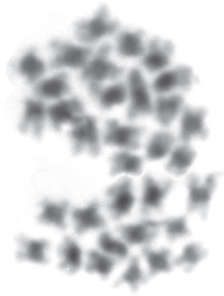

d

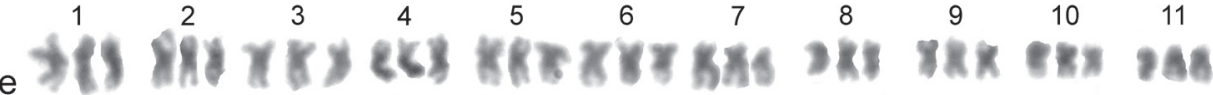

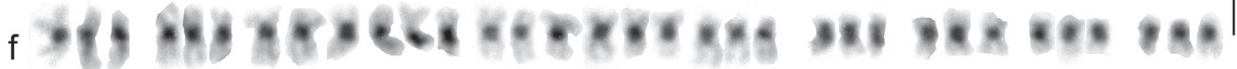

Figure 4. Cantabrogeus triploid species, mitotic chromosomes from mid-gut nuclei. a-d the chromosomes as found $\mathbf{a}, \mathbf{c}$ unbanded $\mathbf{b}, \mathbf{d}$ the same nuclei C-banded $\mathbf{e}, \mathbf{f}$ karyotypes assembled from the nucleus figured in $\mathbf{a} \& \mathbf{b}$. Scale bar $=5 \mu \mathrm{m}$.
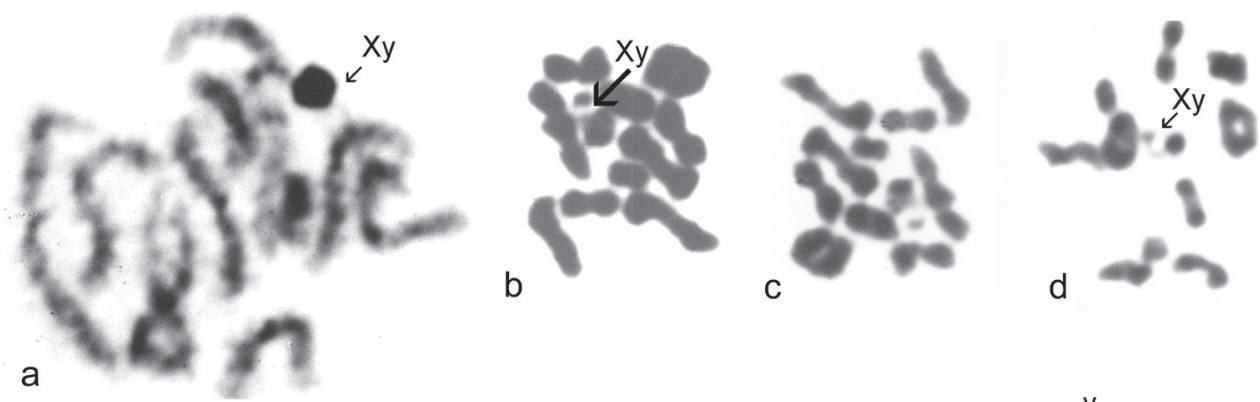

a
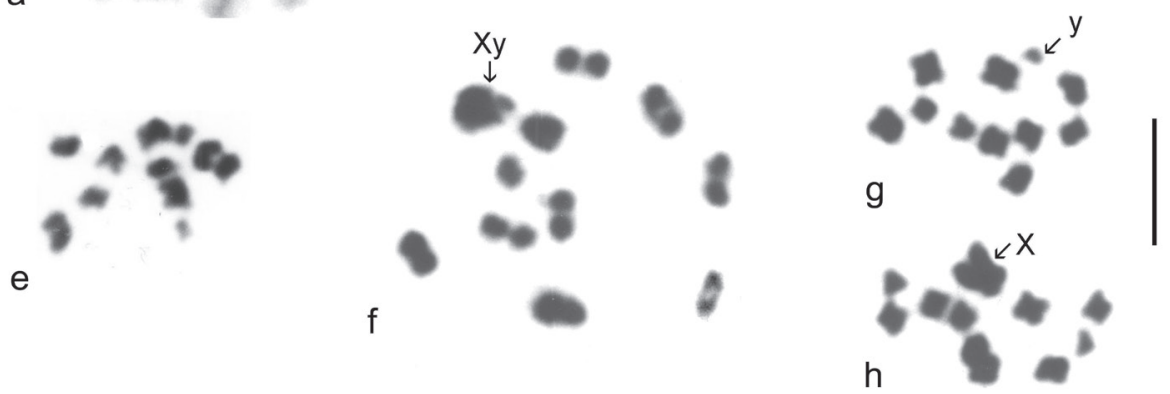

Figure 5. Meiosis of Leiodidae (surface forms). a-e Leiodes calcarata $\mathbf{f}-\mathbf{h}$ Catops coracinus $\mathbf{a}$ prophase I, zygotene $\mathbf{b}-\mathbf{d}$ metaphase I e, metaphase II, $\hat{\delta}$-determining, with y chromosome $\mathbf{f}$ metaphase I $\mathbf{g}, \mathbf{h}$ metaphase II $\mathbf{g} \widehat{\delta}$-determining, with y chromosome $\mathbf{h}$ q-determining, with X chromosome. Scale bar $=5 \mu \mathrm{m}$.

chromosome lengths decrease rather evenly along the karyotype, with pair 11 rather more than half the length of pair 1 . The centromeric C-bands are bold and distinct, but slightly smaller than those of $C$. luquei. There is no chromosome of this species which invites obvious comparison with the $\mathrm{X}$ chromosome of $C$. luquei, so there is no hint in this material about which is the $\mathrm{X}$ chromosome. 


\section{Phylogenetic placement of the triploid species.}

DNA from a specimen captured on June 6, 2009 (ref. IBE-RA34) was analyzed by I. Ribera (Salgado et al. in press), using the genetic methods described in Ribera et al. (2010) and used to establish the phylogenetic relationships of the new triploid species. Cladistic analysis of the sequences identified the sister relationship between the triploid Cantabrogeus sp. and other supraflagellates of the 'Quaestus' series (Fig. 6). The analysis of the obtained sequences shows that Cantabrogeus is the sister group of Fresnedaella lucius and Quaestus pasensis and this clade, in turn, is the sister group of Q. minos and Q. autumnalis (Salgado et al. 2011). Moreover, the whole clade has a sister relationship with the genus Espanoliella. All clades receive high support values. The sister group relationship between Cantabrogeus, Fresnedaella and Quaestus pasensis is recovered in 99-100\% of the bootstrap replicates of RAxML (Fig. 6).

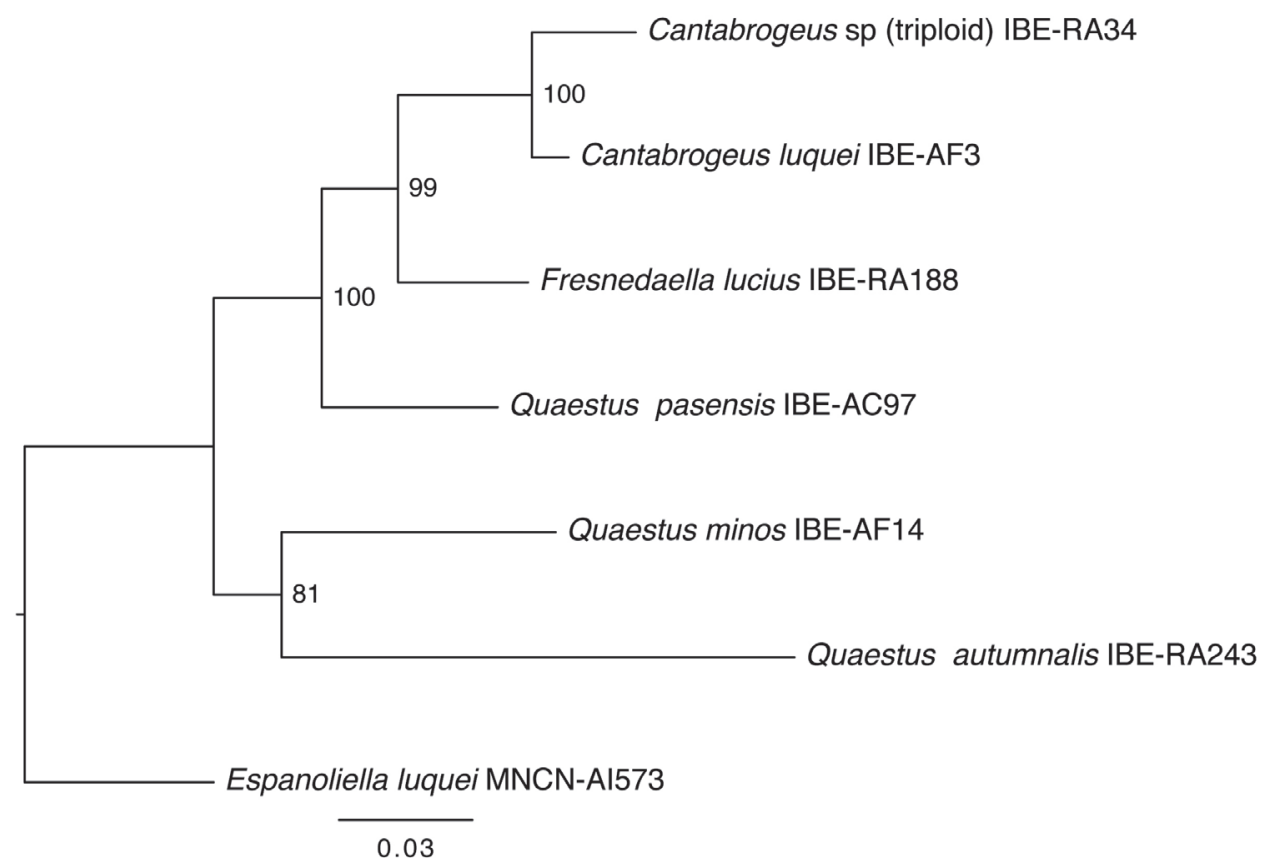

Figure 6. Phylogenetic relationships of triploid Cantabrogeus sp., obtained with the same genes and methodology used by Ribera et al. (2010). Courtesy of I. Ribera, Institute of Evolutionary Biology, CSICUPF (Barcelona, Spain).

\section{Discussion}

As mentioned in the Introduction, the results obtained here appear both surprising and puzzling as all published data indicate a diploid chromosome number of $22+\mathrm{Xy}(\delta)$, which Buzila and Marec (2000) considered to be conservative for the family. The 10 species involved, with their localities of origin and map numbers, 
Table 2. Species of Leptodorini for which chromosome details have been published: species with map No. As shown in Fig. 1, area from which the material was collected, and publication reference.

\begin{tabular}{|c|c|c|}
\hline Species (Map No.) & Area & Reference \\
\hline Speonomus hydrophilus (Jeannel, 1908) (No. 9) & \multirow{8}{*}{$\begin{array}{l}\text { Pyrenees, } \\
\text { France-Spain }\end{array}$} & \multirow[t]{2}{*}{ Durand and Juberthie-Jupeau 1980} \\
\hline S. pyrenaeus (Lespès, 1857) (No.10) & & \\
\hline $\begin{array}{l}\text { Parvospeonomus delarouzeei (Fairmaire, 1860) } \\
\text { (No.11) }\end{array}$ & & \multirow[t]{6}{*}{ Alegre and Escolà 1983} \\
\hline $\begin{array}{l}\text { Troglocharinus elongatus Zariquiey, } 1950 \\
\text { (=variabilis Bellés, 1978) (No. 12) }\end{array}$ & & \\
\hline T. jacasi (Lagar, 1966) (No. 13) & & \\
\hline T. schibii (Español, 1972) (No. 14) & & \\
\hline $\begin{array}{l}\text { T. ferreri (Reitter, 1908) subspecies pallaresi } \\
\text { Bellés, } 1973 \text { (No. 15) }\end{array}$ & & \\
\hline T. kiesenwetteri (Dieck, 1869) (No. 16) & & \\
\hline Pholeuon knirschi Breit, 1911 (No. 17) & \multirow{2}{*}{$\begin{array}{l}\text { Carpathians, } \\
\text { Romania }\end{array}$} & \multirow[t]{2}{*}{ Buzila and Marec 2000} \\
\hline $\begin{array}{l}\text { Drimeotus kovacsi Miller, } 1856 \text { subspecies } \\
\text { viehmanni Ieniştea, } 1955 \text { (No. 18) }\end{array}$ & & \\
\hline
\end{tabular}

are listed in Table 2. This shows that all these species belong in most derived section of the Leptodirini, the infraflagellates of Jeannel (1955) characterised by the basal region of the internal sac of the aedeagus having a Y-shaped ventral sclerite, the Y-piece. Fresneda et al. (2007), in their cladistic analysis of leiodid morphology, concluded that the infraflagellates were a monophyletic group but that the other of Jeannel's groups, the supraflagellates, characterised by having a dorsal flagellum in the basal region of the internal sac of the aedeagus, was a paraphyletic assemblage of less highly derived species. This arrangement is supported and amplified by the DNA work of Ribera et al. (2010). Moreover, Salgado et al. (2011) published an article in which the phylogenetic relationships of Fresnedaella and Cantabrogeus, and its allied taxa were mentioned. These authors show that, while all the species previously studied chromosomally, including those from the Carpathians, belong to the derived infraflagellates, those reported here all belong in the more basal supraflagellate assemblage (Figs 6,7). It therefore seems that the more primitive Leiodidae have a chromosome complement comprising 10 pairs of autosomes and $\mathrm{Xy} / \mathrm{XX}$ sex chromosomes - the only exception being one triploid species of Cantabrogeus. So, far from being the conservative chromosome number for Leiodidae, 11 pairs plus $\mathrm{Xy} / \mathrm{XX}$ sex chromosomes is a derived feature of the advanced infraflagellates. It is also worth noting that if Smith's (1950) suggestion that the ancestral Polyphagan chromosome complement was 9 pairs $+\mathrm{Xy} / \mathrm{XX}$ is correct, then the basic number for Leiodidae involves an increase of one pair of autosomes, while the advanced infraflagellates show an additional increase of one pair. 


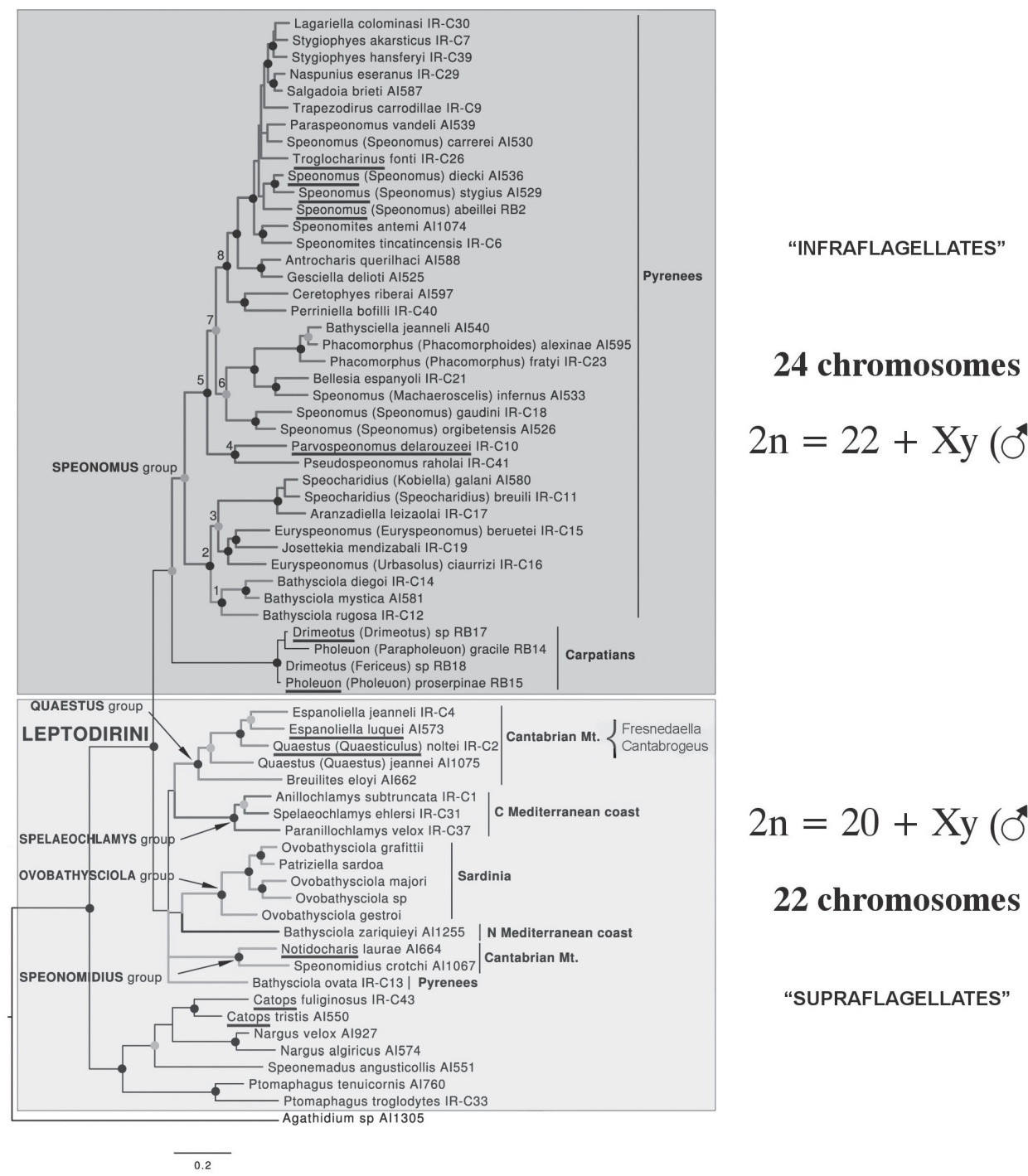

Figure 7. Phylogram obtained from Ribera et al. (2010), modified to show the reconstructed evolution of the chromosome number. Genera whose chromosome complements are known are underlined.

\section{Acknowledgements}

The cave-dwelling specimens referred to in this paper were collected during several biospeleological investigations authorized and funded by the Government of Cantabria (Spain). The studies and explorations in Cantabria were supported in part by grants from the General Direction for Biodiversity of the Regional Government of Cantabria. We thank J.M. Salgado (University of León, Spain), for assistance in collecting speci- 
mens, and I. Ribera (Institute of Evolutionary Biology, CSIC-UPF, Barcelona, Spain) who kindly provided information about molecular studies.

The chromosomal work was carried out in the Natural History Museum, London and the School of Biological Sciences, Royal Holloway, University of London, whom we thank for the facilities to carry out these investigations.

\section{References}

Alegre C, Escolà O (1983) Étude cytogénetique de cinq espèces de Troglocharinus et de Speonomus delarouzeei (Col. Catopidae). Mémoires de Biospéologie 10: 363 - 367.

Buzila RA, Marec F (2000) Conservative chromosome number in the Cholevidae family of cave beetles. Mémoires de Biospéologie 27: 21-23.

Durand J, Juberthie-Jupeau L (1980) Étude cytogénétique de deux espèces de Speonomus (Coléoptères Bathysciinae). Mémoires de Biospéologie 7: 267-271.

Dutton LA, Angus RB (2007) A karyosystematic investigation of a group of sibling species related to Stictotarsus griseostriatus (De Geer) (Coleoptera: Dytiscidae). Comp. Cytogenet. $1: 3-16$.

Fresneda J, Salgado JM, Ribera I (2007) Phylogeny of the western Mediterranean Leptodirini, with emphasis on genital characters (Coleoptera: Leiodidae: Cholevinae). Systematic Entomology 32 (2): 332 - 358. doi: 10.1111/j.1365-3113.2006.00366.x

Jeannel R (1955) L'édéage, initiation aux recherches sur la systématique des Coléoptères. Publications du Museum National d'Histoire Naturelle, Paris 16: 1-155.

Newton AF (1998) Phylogenetic problems, current classification and generic catalogue of world Leiodidae (including Cholevidae). In: Giachino PM, Peck SB (Eds) Phylogeny and Evolution of Subterranean and Endogean Cholevidae (= Leiodidae Cholevinae). Proceedings of XX International Congress of Entomology, Firenze, 1996. Atti Museo Regionale di Scienze Naturali, Torino, 41-178.

Perreau M (2000) Catalogue des Coléoptères Leiodidae Cholevinae et Platypsyllinae. Mémoires de la Société Entomologique de France 4: 1-460.

Perreau M (2004) Leiodidae. In: Löbl I, Smetana A (Eds) Catalogue of Palaearctic Coleoptera. Volume 2. Apollo Books, Stenstrup, 133-203.

Ribera I, Fresneda J, Bucur R, Izquierdo A, Vogler AP, Salgado JM, Cieslak A (2010) Ancient origin of a Western Mediterranean radiation of subterranean beetles. BMC Evolutionary Biology 10: 29. doi: 10.1186/1471-2148-10-29

Salgado JM, Blas M, Fresneda J (2008) Coleoptera, Cholevidae. Ramos MA et al. (Eds) In: Fauna Ibérica. Volume 31. Museo Nacional de Ciencias Naturales, CSIC, Madrid, 799pp.

Salgado JM, Labrada L, Luque CG (2011) Un nuevo género y nueva especie de Leptodirini troglobio de la Cordillera Cantábrica (Cantabria, Espańa): Fresnedaella lucius n. gen., n. sp. (Coleoptera: Leiodidae: Cholevinae). Heteropterus Revista de Entomología 11 (1): 1-12. Salgado JM, Luque, CG, Labrada L, Fresneda J, Ribera I (in press) Revisión del género Cantabrogeus Salgado, 2000 con la descripción de tres nuevas especies hipogeas endémicas de la 
Cordillera Cantábrica (Coleoptera, Leiodidae, Cholevinae, Leptodirini). Animal Biodiversity and Conservation 35.

Smith SG (1950) The cyto-taxonomy of Coleoptera. Canadian Entomologist 82 (3): 58 - 68. doi: $10.4039 /$ Ent8258-3

Smith SG, Virkki N (1978) Animal Cytogenetics 3: Insecta 5: Coleoptera. x + 366 pp. Gebrüder Borntraeger, Berlin - Stuttgart.

Stamatakis A, Hoover P, Rougemont J (2008) A rapid bootstrap algorithm for the RAxML web servers. Systematic Biology 57 (5): 758-771. doi: 10.1080/10635150802429642 